\title{
Android-Based 3D Visualization of Indonesia Medicinal Plants
}

\author{
Lita Karlitasari ${ }^{1}$, Ismanto ${ }^{2}$, Agung Prajuhana Putra ${ }^{\star^{3}}$ \\ ${ }^{1,3}$ Computer Sciences Study Program, Faculty of Mathematic and Natural Science, \\ ${ }^{2}$ Biology Study Program, Faculty of Mathematic and Natural Science, Pakuan University, Jl.Pakuan \\ PO.BOX.452, Ciheuleut, Bogor 16143. \\ Corresponding author, e-mail: rawit77@yahoo.com ${ }^{1}$, ismanto02@google.co.id ${ }^{2}$, \\ prajuhana.putra@unpak.ac.id ${ }^{3}$
}

\begin{abstract}
$3 D$ visualization of medicinal plants is the result of the transformation that resembles the original image and is dynamic, so it can be viewed in detail from all sides. Image capture is performed with a level of clarity must be at least $70 \%$ so it would be easy when designing a 3D visualization. The medicinal plants collected came from Bogor Botanical Gardens of 11 plants, Ciapus - Bogor of 16 plants, and CibodasBotanical Gardens of 37 plants. The image capture was done by using the comparison scale of human height, stem, flowers, fruits, and leaves both look forward and backward. Application development was done through the objects collection, object segmentation, object texture creation and $3 D$ object creation. The application of $3 D$ visualization medicinal plants can be enlarged and reduced, and rotated well to the right, left, up, and down. The medicinal plant that appears in the application was in Indonesian and Latin names, taxon and the descriptions. Therefore the general public, students, and researchers can utilize the plant objects much better.
\end{abstract}

Keywords: visualization, 3D, plants, medicine

Copyright $\odot 2017$ Institute of Advanced Engineering and Science. All rights reserved.

\section{Introduction}

Visualization is the engineering of drawings, diagrams, or animations creation to perform of information. Recently, visualization has been developed and are widely used for the purposes of science, engineering, product design visualization, education, interactive multimedia, medical, and so on. Visualization has been the development of computer technology that can improve the real world with very detailed predictions and also to create a model and simulate the real-world. Modeling is tomakeof an object looks like a living object. Through the concept and design process, the entire object can be shown in three dimensions. One of the aim by using the multimedia as a tool to create dynamic and interactive presentation that combines text, graphics, animation, audio and video images is to increase the effectiveness of information delivery.

Medicinal plants are plants that have medicinal properties and are used as a medicine in the treatment and prevention of disease. It means that contain active substances that serve treating certain diseases or if it does not contain certain active substances thenit contains a resultant effect or synergy of various substances that serve treat [1]. Medicinal plants do not mean plants that grown as a medicinal plant. Medicinal plants that classified as spices or herbs, hedges, fruit trees, vegetables or even wild plants can also be used to treat various diseases. The findings of modern medicine are growing rapidly caused the traditional medicine looks outdated. Many modern medicines are made from medicinal plants, but the manufacturing process was done so impressed the modern clinical laboratories. The discovery of modern medicine also supports the use of traditional medicines [2]. Herbs and medicinal plant species are defined as plants that some part or the whole plant and exudates plant was used as a medicine, ingredient or drug. Exudates of plants are the contents of cells that spontaneously out of the plant or in a certain way deliberately left out from it cell. Plant exudates could be substances or other vegetable materials which in some way separated or isolated from plants [3]. 
In a previous study (2013-2014) performed by Lita Karlitasari and Ismanto [10] has developed an android-based digital dictionary of plant taxonomy for biology student. The dictionary has been copyrighted in the Directorate General of Intellectual Rights, registration number of C00201404206 and has been published through Google Play. The dictionary received a positive response from the community that reach into 5,000 downloads (statisticalandroid app). Thereis a search facility for local name and Latin name, and display the planttaxon of kingdom, subkingdom, division, subdivision, class, subclass, ordo, family, genus, and species. It also fitted with a description and some photos of flowers, leaves, fruits, stems, and more.

However, due to the photos displayed are static, sometimes when it magnified then the picture becomes fragmented due to the low resolution andmade it hard for the users to learn the object of these plants. Therefore, the aim of this study is todevelopthe three-dimensional visualization of plants in the existing digital dictionary of plant taxonomy. Although the object display will be transformed into image and not the original photo, but the image that will be created should resemble the original photo and are dynamic, so it can be enlarged as desired, and can be seen in detail from all sides. Therefore, the use of some related software is expected to makethe three-dimensional objects plant becomes better.

\section{Research Method}

IMSDD (Interactive Multimedia System Design and Development) was the method used in this study. There are severalsteps that should be passed.

1. System Requirements Stage

a. Adobe Photoshop + Blender

b. Unity 3D

2. Design Considerations Stage

Design consideration is a design of construction the 3D plants object as shown in Figure 1.
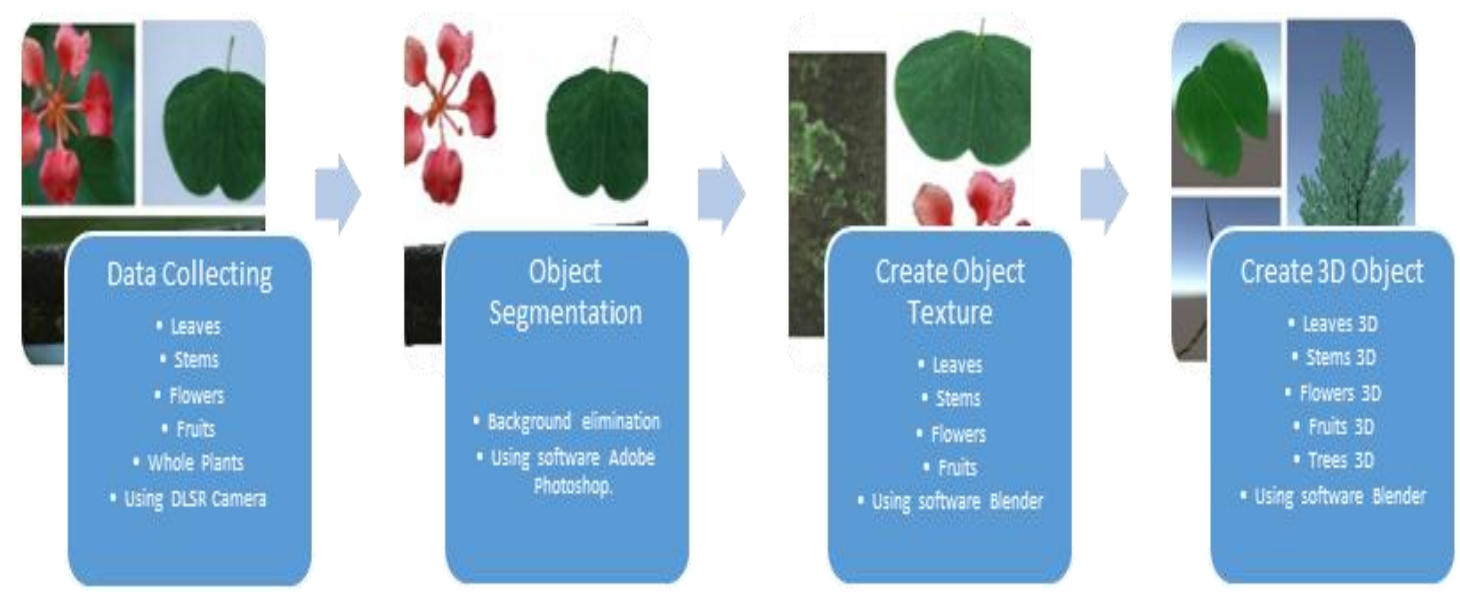

Figure 1. Flowchart of 3D object construction

3. Implementation Stage

Once the texture is complete, the next step was to make 3D objects with Blender software. In the construction of $3 \mathrm{D}$ objects, the characteristics that are created should be correctly because it will affect the results. The object characteristics was the size (length multiplied by width and multiplied by height), form and texture.

4. Evaluation Stage

a. Formative: keep track of progress toward achievement of the innovation in the implementation. 
b. Summative: keep track to the effectiveness of innovation when it is completed, compared with the target requested.

\section{Results and Analysis}

The implementation of the 3D application was done through data collection, object segmentation, create object texture and create 3D object. The application will start from the splash screen followed by the main menu to select one of the desired plants. Once elected, you will find images by selecting part of good overall, stems, leaves, flowers, or fruit. Even there you will find a description of the plant. As for the plant's own image, because the three-dimensional shape, you can change the size of either enlarged or reduced, or changes the direction of the play, right, left, up, or down. The results that have been made were shown in Figure 2 and Figure 3.

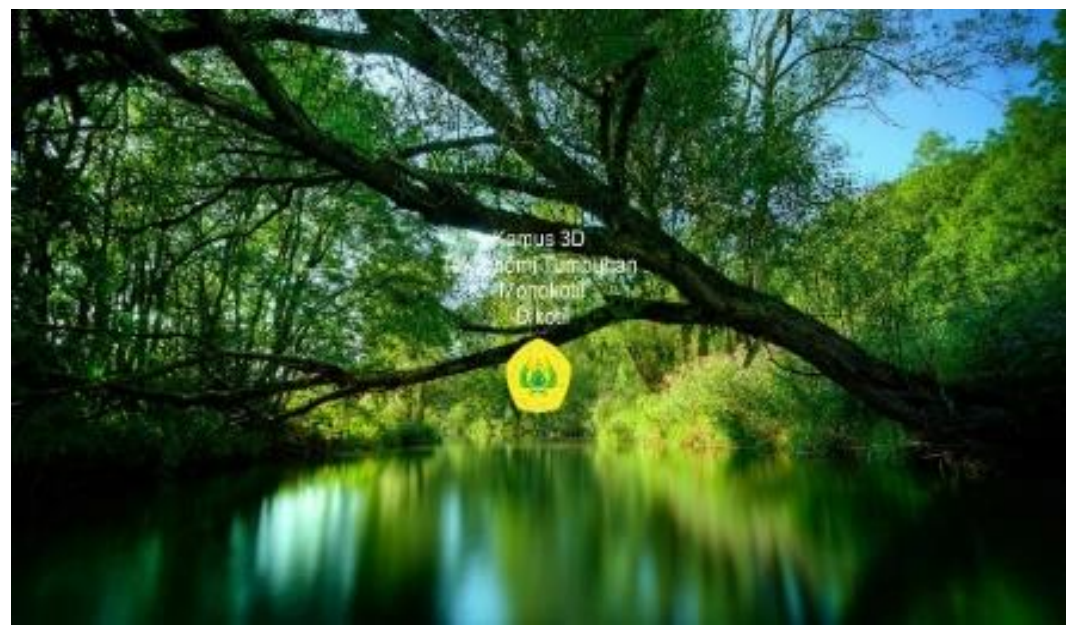

Figure 2. Splash Screen

1. Evaluation

a. Formative: keep track of progress toward achievement of the innovation in the implementation.

Helpful for the user to enlarged and reduced, rotated well to the right, left, up, and down.

b. Summative: keep track to the effectiveness of innovation when it is completed, compared with the target requested.

Summative evaluation proper to determine the suitability of the product compared to other products. The validation was carried out by the Plant Taxonomy Lecturer of Pakuan University - alumni of Biological Studies Program, researchers from Cibodas Botanical Garden, and LIPI researchers of Botany and Ecology. 


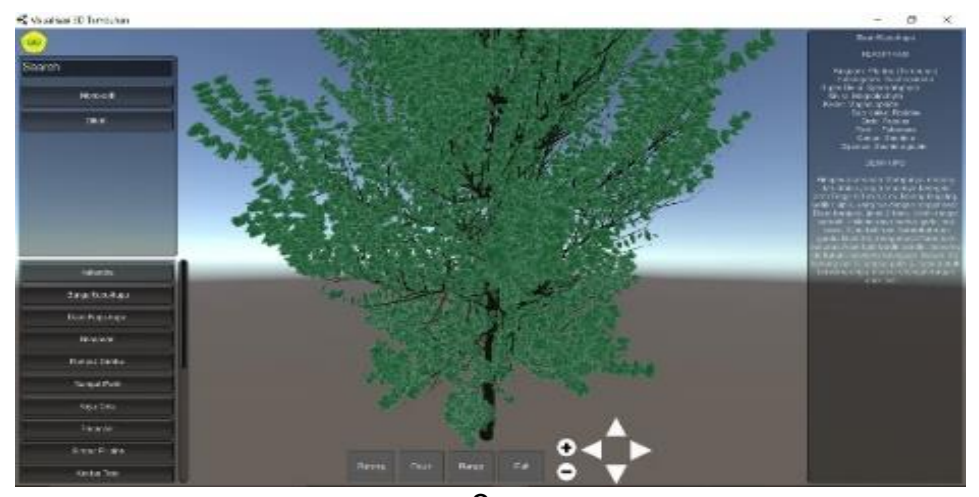

$3 a$

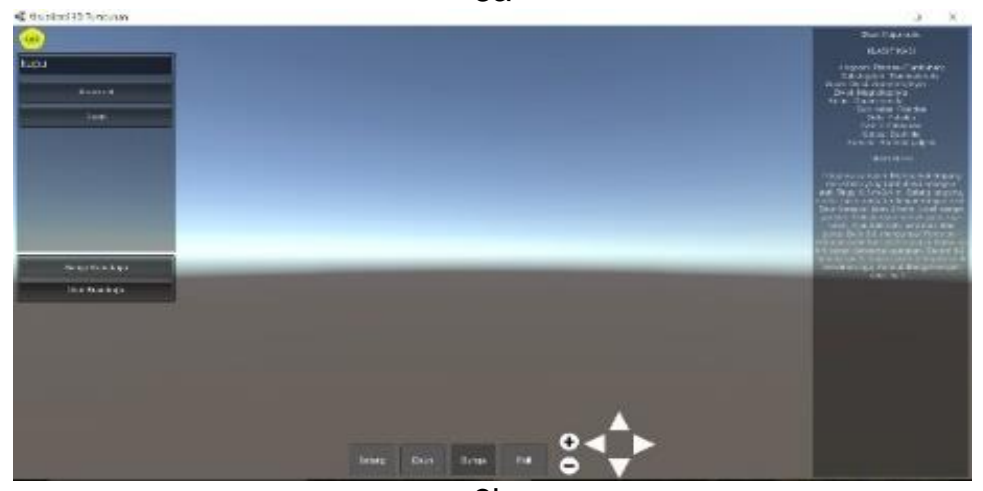

$3 b$
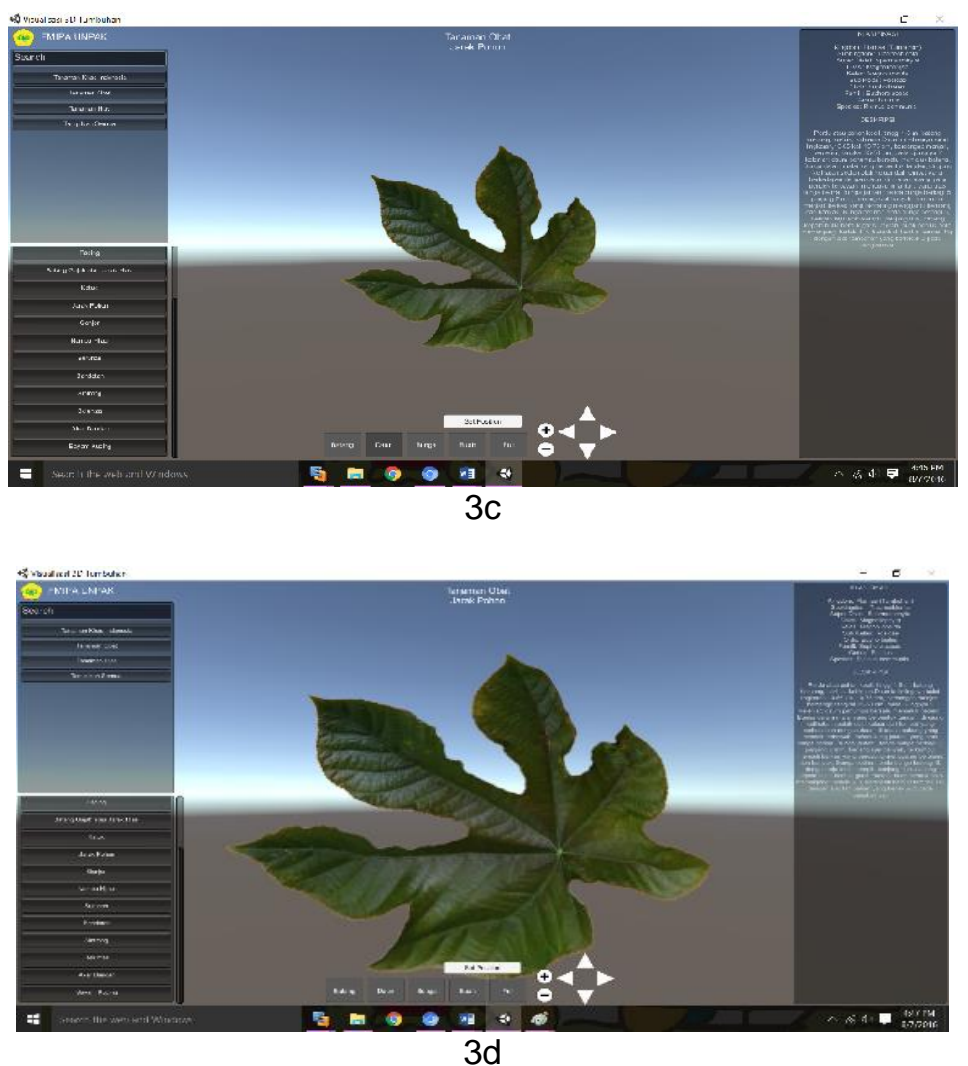

Figure 3. Application display: 3a. Main menu, 3b. Searching and sorting, 3c. Leaves design, 3d. Leaves design and zoom 


\section{Conclusion}

3D visualization of medicinal plants was the outcome of the image transformation. It was made to resemble the original image and are dynamic, so it can be enlarged as desired, and can be seen in detail from all sides. The Image capture re-takenwas done because the photos are required to be at least $70 \%$ level of clarity to be easy when designing the model of $3 \mathrm{D}$ visualization. The medicinal plants collected came from Bogor Botanical Gardens of 11 plants, Ciapus - Bogor of 16 plants, and Cibodas Botanical Gardens of 37 plants. The image capture was done by using the comparison scale of human height, stems, flowers, fruits, and leaves both look forward and backward. Application development was done through the objects collection, object segmentation, object texture creation and 3D object creation. The application of 3D visualization medicinal plants can be enlarged and reduced, and rotated well to the right, left, up, and down. The medicinal plants that appears in the application was in Indonesian and Latin names, taxon and the descriptions. Therefore the general public, students, and researchers can utilize the plant objects much better.

\section{References}

[1] Hariana and Arief. Tumbuhan Obat dan Khasiatnya. Penebar Swadaya. Jakarta. 2009. Series of 1 and 3.

[2] Hembing. Tanaman Berkhasiat Obat. Jakarta: Pustaka Kartini. 1996; 1(5).

[3] Wijaya Kusuma H. Tanaman Berkhasiat Obat di Indonesia. Pustaka Kartini, Jakarta. 1996; IV: 126.

[4] Kardiman A and Ruhnayat A. Budidaya Tanaman Obat Secara Organik. Agromedia Pustaka. Tangerang. 2003.

[5] Rahayu S and Sunarlim N. Konservasi tumbuhan obat langka purwoceng melalui pertumbuhan minimal. Plasma Nutfah Bulletin. 2003; 8(1): 29-33

[6] Alikodra HS. Kontribusi kalangan akademik dalam pengembangan kawasan konservasi. Seminar Sehari Pengembangan Wilayah Berbasis Keanekara-gaman Hayati. Cibodas Botanical Garden. 2000. 6 pages.

[7] Lita Karlitasari and Ismanto. Pengembangan kamus digital taksonomi tumbuhan berbasis android. 2014.

[8] Lian LU. Research on How to Design an Android-based RFID Reader. TELKOMNIKA Indonesian Journalof Electrical Engineering. 2014; 12(9): 6431-6436.

[9] Wei Yang, Kun Hou, Xintong Yu, Fanhua Yu. A Resizing Method for 3D Visualization of Digital Elevation Models. TELKOMNIKA Indonesian Journalof Electrical Engineering. 2014; 12(5): 4050-4055.

[10] Zhao Ming, Yan Zhengbo, Zhou Liukun, Wang Huijie, XuXiaogang. The Research of Power plant Operationg Data Based on Real-time Digital filtration technology. TELKOMNIKA Indonesian Journalof Electrical Engineering. 2013; 11(10): 6080-6086. 